Original Research Paper

\title{
Application of Dry Probiotic Rabal to Increase Growth Performance of Catfish (Clarias sp.)
}

\author{
Lukman Anugrah Agung ${ }^{1 *}$ \& Imas Rohmawati ${ }^{2}$ \\ ${ }^{1}$ Program Studi Ilmu Perikanan, Universitas Sultan Ageng Tirtayasa, Indonesia; \\ ${ }^{2}$ Program Studi Agroekoteknologi, Universitas Sultan Ageng Tirtayasa, Indonesia
}

\author{
Article History \\ Received : September $16^{\text {th }}, 2021$ \\ Revised : October $12^{\text {th }}, 2021$ \\ Accepted : November $02^{\text {th }}, 2021$ \\ Published : November $12^{\text {th }}, 2021$ \\ *Corresponding Author: \\ Lukman Anugrah Agung, \\ Program Studi Ilmu Perikanan, \\ Universitas Sultan Ageng \\ Tirtayasa, Serang, Indonesia; \\ Email: \\ lukman.anugrah@untirta.ac.id
}

\begin{abstract}
Catfish have become an important contributor to fish production in Indonesia. Catfish consumption in Indonesia always increases every year. To meet the demand for catfish consumption, it was carried out with an intensive aquaculture system. However, the high cost of feed has been identified as a significant constraint in catfish farming. Efforts to increase catfish growth are needed to reduce feed costs, one of the efforts is by probiotic supplementation through the feed. This study was carried out to determine the best dose of probiotic rabal dried addition to increasing catfish growth. The experiment used four treatments and three replications. Probiotic rabal dried doses: $0 \%$ of feed (A)/feed (control), $5 \%$ of feed (B), $10 \%$ of feed (C), and (D) $15 \%$ of were used as treatment. The feed was given ad-satiation with a frequency of feeding three times a day. Observations were made for 45 days. The results indicated that the $\mathrm{B}$ treatment of $5 \%$ of feed gave the best absolute weight growth and feed conversion ratio. While catfish fish survival rate was not significantly different on all treatments.
\end{abstract}

Keywoard: Catfish, dried probiotic rabal, growth

\section{Pendahuluan}

Ikan lele (Clarias sp.) adalah ikan sebagai sumber protein hewani yang telah berkembang sebagai komoditas budidaya perikanan. Teknologi budidaya ikan lele yang terus berkembang berpengaruh signifikan terhadap efisiensi budidaya ikan lele serta didukung oleh ketersediaan pasar yang luas menyebabkan tingginya minat pembudidaya untuk membudidayakan ikan lele. Data KKP (2016) menunjukkan bahwa produksi ikan lele mengalami peningkatan sebesar 21,31\% selama lima tahun pada (2011-2015). Selanjutnya, produksi ikan lele pada tahun 2017 yaitu 1,77 juta ton, naik $131 \%$ dari tahun 2016 dengan nilai awal 764.797 ton (KKP, 2018).

Peningkatan produksi lele selama ini dilakukan melalui sistem budidaya intensif. Model budidaya intensif adalah budidaya ikan dengan pemberian pakan buatan yang berkualitas dan peningkatan padat tebar. Namun, kendalanya adalah pada biaya pakan

This article is licensed under a Creative Commons Attribution 4.0 International License. yang mencapai $60-70 \%$ dari biaya budidaya ikan (Syamsunarno dan Sunarno, 2014; Arief et al., 2014). Oleh karena itu, diperlukan upaya meningkatkkan pertumbuhan dan efisiensi pakan ikan lele melalui pemberian pakan dengan penambahan probiotik sehingga dapat menekan biaya produksi budidaya ikan lele.

Penggunaan probiotik pada kegiatan budidaya perikanan telah terbukti dapat meningkatkan pertumbuhan dan ketahanan tubuh ikan terhadap penyakit (El-rhman et al., 2009). Nayak (2010) menyatakan bahwa pemberian probiotik dengan dosis optimal dapat menjaga keseimbangan mikroba saluran pencernaan ikan. Dosis optimum probiotik tersebut dapat bervariasi tergantung dari spesies ikan dan tingkat imunitas tubuhnya.

Menurut Leroy dan De Vuyst (2004), molase diperlukan dalam kultur probiotik rabal sebagai sumber nutrisi bakteri melalui fermentasi untuk menghasilkan asam laktat. Bakteri asam laktat mampu menghasilkan senyawa aromatik, polimer gula, senyawa antimikroba, serta vitamin dan enzim yang 
bersifat probiotik. Selain itu, bakteri asam laktat dapat menekan populasi bakteri patogen serta limbah sisa pakan dan metabolisme ikan (Risdianto et al., 2016). Pemberian probiotik rabal telah terbukti mempengaruhi pertumbuhan, kelangsungan hidup, dan konversi pakan pada ikan barramundi dengan konsentrasi terbaik yaitu 20\% (g /mL) (Anna et $a l ., 2019)$. Selain itu, pemberian probiotik rabal yang dihasilkan melalui fermentasi spontan pada udang galah dengan dosis yang berbeda menghasilkan efek yang signifikan pada laju pertumbuhan dan rasio konversi pakan dan tidak ada efek signifikan pada kelangsungan hidup larva udang galah. Selanjutnya, dosis rabal terbaik adalah pada dosis 225 ppm (Dachi et al., 2019).

Probiotik dalam bentuk cair memiliki kelemahan diantaranya yaitu viabilitas yang menurun selama penyimpanan serta mudah rusak oleh pengaruh lingkungan. Sementara itu, probiotik kering memiliki kelebihan diantaranya adalah dapat diaplikasikan dengan mudah dan viabilitas yang lebih tinggi (Weinbreck et al., 2010). Oleh karena itu, diperlukan aplikasi probiotik rabal dalam bentuk kering dengan menambahkan bahan pengisi atau filler yang murah dan mudah didapat. Bahan pengisi yang dapat digunakan adalah tepung dedak karena harganya relatif murah, bersifat higroskopis serta dapat berfungsi sebagai sumber energi (Lestari et al., 2014; Surianti et al., 2021). Namun demikian, belum ada penelitian yang menjelaskan tentang aplikasi probiotik rabal dalam bentuk kering. Berdasarkan uraian di atas, penelitian ini bertujuan untuk mengevaluasi pengaruh penambahan probiotik kering rabal untuk meningkatkan kinerja pertumbuhan ikan lele (Clarias sp.).

\section{Bahan dan Metode}

\section{Rancangan percobaan}

Rancangan penelitian menggunakan rancangan acak lengkap (RAL). Analisis data menggunakan metode sidik ragam (ANOVA) pada tingkat kepercayaan $95 \%$, apabila terdapat perbedaan yang nyata maka dilanjutkan dengan uji lanjut Duncan. Percobaan terdiri atas 4 perlakuan 3 ulangan. Perlakuan pada penelitian ini yaitu pemberian pakan yang ditambah probiotik kering rabal pada dosis yang berbeda yaitu A: 0\%, B: 5\%, C: 10\%, dan D: $15 \%$.

\section{Alat dan Bahan}

Alat dan bahan pada penelitian adalah wadah pemeliharaan berupa bak bulat berukuran $(41 \times 50 \times 57 \mathrm{~cm})$, selang aerasi, blower, batu aerasi. Sedangkan bahan penelitian yaitu ikan lele, pakan pelet, dedak padi, dan probiotik kering rabal.

\section{Pembuatan probiotik kering rabal}

Pembuatan probiotik rabal mengacu pada (Dachi et al., 2019), dengan komposisinya adalah $9 \mathrm{~L}$ aquades, 0,5 $\mathrm{L}$ tetes tebu (molase), 0,25 $\mathrm{L}$ air kelapa, serta inokulan rabal sebanyak $0,25 \mathrm{~L}$ dihomogenkan dalam wadah berukuran $10 \mathrm{~L}$, kemudian dilakukan fermentasi selama 7 hari. Selanjutnya, pembuatan probiotik kering rabal mengacu pada (Sutrisna et al., 2017). Probiotik rabal dicampurkan ke dalam tepung dedak yang sebelumnya telah disaring menggunakan saringan plastik berdiameter $1 \mathrm{~mm}$ selanjutnya disterilkan dengan autoklaf. Pencampuran probiotik rabal dengan tepung dedak dilakukan dengan penyemprotan sebanyak $100 \%$ dari bobot tepung dedak (v/w). Kemudian dilakukan pengeringan tepung dedak pada suhu ruang.

\section{Perlakukan ikan uji}

Ikan lele (Clarias sp.) sebagai ikan uji pakan pada penelitian ini memiliki bobot $6.03 \pm 0.38$ g/ekor yang berasal dari Balai Benih Ikan Baros, Kab. Serang. Ikan tersebut kemudian diadaptasikan terlebih dahulu selama 7 hari, kemudian ditebar secara acak dalam 12 wadah penelitian. Pemeliharaan ikan uji selama 45 hari. Pemberian pakan perlakuan sebanyak 3 kali pada pukul 08.00, 13.00, dan 16.00 dilakukan dengan metode sekenyangnya (ad-satiation). Pergantian air dilakukan setiap 3 hari sekali sebanyak $20 \%$ dari volume air.

\section{Persiapan pakan uji}

Pakan uji perlakuan merupakan pakan komersial dengan kadar protein 32\% yang ditambahkan dengan probiotik kering rabal sesuai dosis perlakuan (w/w), kemudian dilakukan proses pelapisan (coating) menggunakan perekat pelet komersial sebagai binder. Pakan tersebut kemudian dikeringudarakan dalam suhu ruang.

\section{Parameter uji}

Parameter kinerja pertumbuhan yang 
diukur pada penelitian ini meliputi laju pertumbuhan spesifik (LPS), rasio konversi pakan (RKP) dan kelangsungan hidup ikan. Nilai LPS dihitung menggunakan formula dari Huisman (1987). Rasio konversi pakan dihitung menggunakan formula dari Watanabe (1988). Tingkat kelangsungan hidup diukur dengan membagi jumlah ikan hidup di akhir penelitian dengan jumlah ikan hidup pada awal penelitian.

\section{Hasil dan Pembahasan}

\section{Laju Pertumbuhan spesifik (LPS)}

Pemberian probiotik kering rabal selama 45 hari pemeliharaan menunjukkan pengaruh terhadap LPS ikan lele. LPS ikan lele selama penelitian tersaji pada Gambar 1. Perlakuan B menunjukkan LPS tertinggi sebesar $4.25 \pm 0.15 \%$, yang tidak berbeda nyata $(\mathrm{P}>0.05)$ dengan perlakuan $\mathrm{C}$ senilai $4.23 \pm$ $0.07 \%$, namun berbeda nyata $(\mathrm{P}<0.05)$ dengan perlakuan D $3.88 \pm 0.06 \%$ dan perlakuan A sebesar $3.87 \pm 0.06 \%$. Perlakuan A menunjukkan nilai LPS terendah.

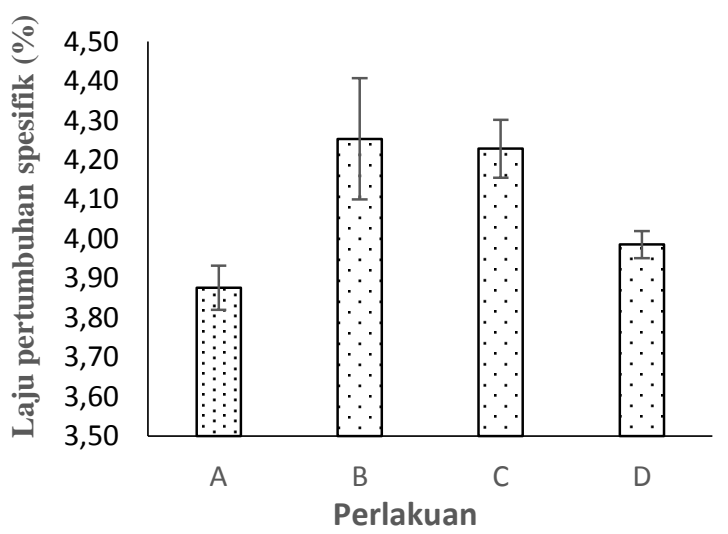

Gambar 1. Laju pertumbuhan spesifik ikan lele selama penelitian

\section{Rasio Konversi Pakan (RKP)}

Rasio konversi pakan ikan lele selama 45 hari pemeliharaan yaitu pada Gambar 2 . Pemberian probiotik kering rabal melalui pakan selama 45 hari pemeliharaan diketahui memberikan pengaruh terhadap rasio konversi pakan ikan lele. RKP mulai dari yang terendah yaitu perlakuan B sebesar $0.96 \pm 0.08$, kemudian C

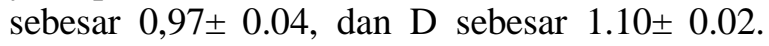
Pada parameter RKP, perbedaan yang nyata $(\mathrm{P}<0.05)$ yaitu pada perlakuan $\mathrm{A}$ dengan perlakuan $\mathrm{B}$ dan $\mathrm{C}$ dengan nilai secara berurutan yaitu $1.17 \pm 0.03,0.95 \pm 0.07$ dan $0.96 \pm 0.03$.
Sedangkan perlakuan A dan D tidak menunjukkan perbedaan yang nyata $(\mathrm{P}>0.05)$.

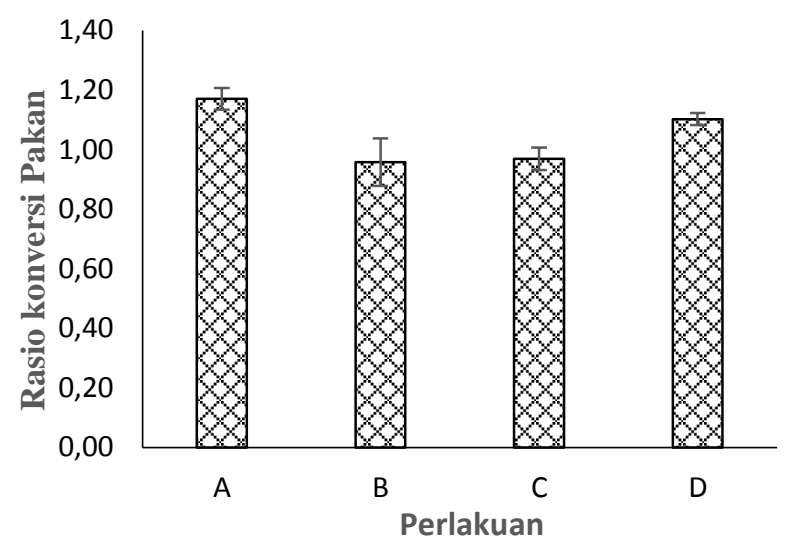

Gambar 2. Rasio konversi pakan ikan lele selama pemeliharaan

\section{Kelangsungan hidup ikan}

Kelangsungan hidup ikan lele setelah periode budidaya selama 45 hari terdapat pada Gambar 3. Penambahan probiotik kering rabal pada dosis yang berbeda tidak menunjukkan pengaruh yang nyata terhadap kelangsungan hidup ikan lele $(\mathrm{P}>0.05)$. Nilai tingkat kelangsungan hidup ikan lele menunjukkan nilai yang sama pada masing-masing perlakuan yaitu sebesar $100 \pm 0 \%$

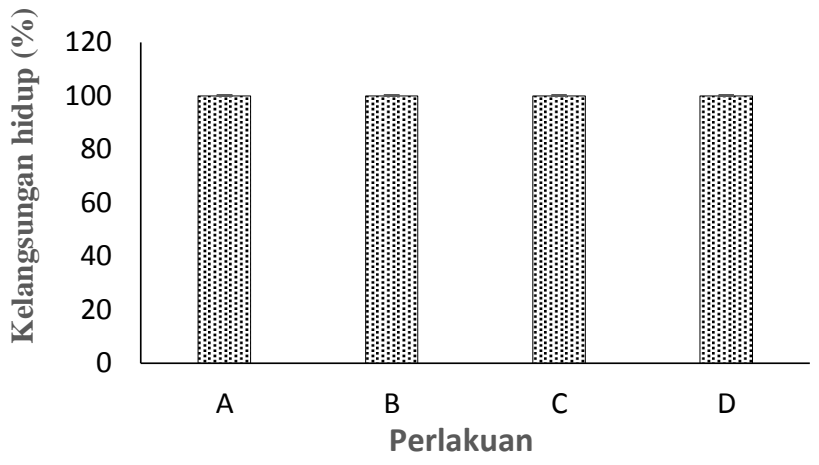

Gambar 3. Kelangsungan hidup ikan lele selama pemeliharaan

\section{Pembahasan}

\section{Laju Pertumbuhan Spesifik (LPS)}

Pertumbuhan spesifik merupakan pertambahan bobot ikan lele per hari selama periode penelitian yang dilakukan. Data rerata LPS ikan lele tersaji pada Gambar 1. Hasil tersebut menunjukkan bahwa kombinasi ragi dan bakteri asam laktat dalam rabal yang diberikan melalui pakan menunjukkan peningkatkan LPS 
ikan lele. Menurut Hoseinifar et al. (2018) peningkatan pertumbuhan ikan yang disuplementasi probiotik disebabkan oleh peningkatan aktivitas pencernaan sebagai akibat dari peningkatan aktivitas enzimatik dan sintesis vitamin.

Menurut Catalán et al. (2018) mekanisme kerja utama probiotik adalah menjaga keseimbangan mikroba dalam saluran pencernaan melalui kompetisi nutrisi serta kompetisi reseptor untuk penempelan bakteri menguntungkan pada sel epitel usus. Bakteri asam laktat dalam rabal dapat menempel dan membentuk koloni di usus ikan sehingga menekan bakteri patogen dalam usus ikan lele. Selanjutnya, bakteri asam laktat menghasilkan enzim exogenous sehingga nutrisi dari pakan ikan akan lebih mudah dicerna dan diabsorbsi oleh ikan sehingga menghasilkan peningkatan pertumbuhan (Dawood et al., 2019). Selain itu, yeast (ragi) dalam rabal juga menghasilkan efek menguntungkan bagi ikan melalui produksi beberapa substrat energi pada sel-sel intestinal sehingga meningkatkan pencernaan dan penyerapan nutrisi bagi ikan lele (Jullianty et al., 2020). Hasil ini sejalan dengan hasil penelitian Mapenzi et al. (2021) bahwa pemberian kombinasi bakteri asam laktat Lactobacillus plantarum dan yeast Saccharomyces cerevisiae mampu meningkatkan pertumbuhan ikan nila.

\section{Rasio Konversi Pakan (RKP)}

RKP merupakan perbandingan antara jumlah pakan yang diberikan dengan jumlah bobot ikan yang dihasilkan selama periode budidaya. RKP merupakan indikator dalam menilai kelayakan usaha budidaya perikanan. Rendahnya RKP menunjukkan efesiensi pakan yang lebih baik sedangkan tingginya RKP menunjukkan tingkat efisiensi pakan yang kurang baik (Iskandar \& Elrifadah, 2015). Nilai rasio konversi pakan tersaji pada Gambar 2. Nilai RKP terendah yaitu pada perlakuan B $(5 \%)$ dengan nilai $0.96 \pm 0.08$ yang berbeda nyata $(\mathrm{P}<0.05)$ dengan perlakuan A dan D namun tidak berbeda nyata dengan perlakuan C. Nilai RKP perlakuan yang lebih rendah pada penelitian ini sejalan dengan hasil penelitian (Setiyaningsih et al., 2018) yang menunjukkan bahwa suplementasi mikrokapsul probiotik Bacillus cereus P22 dan Staphylococcus lentus L1K melalui pakan menghasilkan nilai RKP yang lebih rendah daripada kontrol. Nilai RKP tertinggi yaitu pada perlakuan A $(0 \%)$ dengan nilai $1.17 \pm 0.03$ menunjukkan bahwa efisiensi pakan pada perlakuan kontrol lebih rendah daripada perlakuan probiotik

Menurut Fu et al. (2007), energi sebagai hasil pencernaan dan penyerapan nutrisi yang berasal dari pakan ikan sebagian digunakan untuk metabolisme dan pertumbuhan, kemudian sisanya dibuang dalam bentuk feses. Bakteri probiotik dapat masuk melalui pakan, selanjutnya akan menempel dan berkembang dengan membentuk koloni dalam usus ikan kemudian mengeluarkan beberapa enzim pencernaan, seperti amilase, lipase dan protease. Enzimenzim pencernaan ini dapat membantu meningkatkan kecernaan pakan ikan melalui katabolisme nutrisi utama seperti protein, lemak, dan karbohidrat menjadi komponen nutrisi yang lebih sederhana sehingga penyerapan nutrisi menjadi lebih optimal Bagheri et al. (2008). Hal ini akan menghasilkan menurunnya nilai konversi pakan, yang berarti bahwa efisiensi pemanfaatan pakan menjadi lebih baik.

\section{Kelangsungan hidup Ikan}

Nilai kelangsungan hidup seluruh perlakuan menunjukkan nilai yang tidak berbeda nyata yaitu $100 \pm 0 \%$. Hasil ini menunjukkan bahwa pemberian probiotik kering rabal tidak mengganggu kesehatan ikan lele sehingga ditunjukkan dengan nilai kelangsungan hidup ikan yang tinggi. Hasil penelitian ini sejalan dengan penelitian (Noordin dan Apriani, 2021) bahwa pemberian jenis bakteri probiotik yang berbeda melalui pakan tidak berpengaruh nyata terhadap kelangsungan hidup lele. Nayak, (2010) mengemukakan bahwa pemberian probiotik yang sesuai dengan kebutuhan ikan dapat meningkatkan jumlah bakteri menguntungkan dalam saluran cerna ikan sehingga meningkatkan kesehatan ikan. Selain itu, menurut Kordi (2009) tingginya kelangsungan hidup ikan ditentukan oleh komposisi nutrisi pakan yang diberikan serta kualitas air pada budidaya ikan.

\section{Kesimpulan}

Pemberian probiotik rabal memberikan pengaruh nyata terhadap kinerja pertumbuhan ikan lele yang meliputi laju pertumbuhan spesifik (LPS), rasio konversi pakan (RKP), serta 
kelangsungan hidup ikan lele. Perlakuan B (5\%) menunjukkan nilai kinerja pertumbuhan ikan lele tertinggi dengan LPS sebesar $4.25 \pm 0.15 \%$, RKP sebesar $0.96 \pm 0.08$, serta kelangsungan hidup sebesar $100 \% \pm 0$.

\section{Ucapan Terima Kasih}

Ucapan terima kasih kasih disampaikan kepada Universitas Sultan Ageng Tirtayasa yang telah memberikan dana penelitian dengan nomor SK.202/UN43/KPT.PT.01.02/2021.

\section{Referensi}

KKP (2016). KKP kembangkan teknologi budidaya ikan lele ramah lingkungan metode bioflok. [Online]. Website: http://www.djpb.kkp.go.id/arsip/c/451/kk p-kembangkan-metode-bioflok-untukkeberlanjutan/?category_id= [diakses 1 september 2021].

KKP (2018). Subsektor perikanan sepanjang tahun 2017 menunjukkan kinerja positif. [Online]. Website: https://kkp.go.id/ djpb/artike1/3113-subsektor-perikananbudidaya-sepanjang-tahun-2017menunjukkan-kinerja-positif [diakses 1 September 2021].

Anna, L., Muhammadar, \& Sahidhir, I. (2019). The Effect Of Probiotics (RABAL) On Application In Diet With Different Doses On Growth, Survival And Feed Conversion Of Barramundi (Lates Calcarifer). IOP Conference Series: Earth and Environmental Science, 348(1), 1-7. https://doi.org/10.1088/17551315/348/1/012102

Arief, M., Fitriani, N \& Subekti, S. (2014). The Pengaruh pemberian probiotik berbeda pada pakan komersial terhadap pertumbuhan dan efisiensi pakan ikan lele sangkuriang (Clarias sp.). Jurnal Ilmiah Perikanan dan Kelautan, 6(1), 50-53.

Bagheri, T., Hedayati, S. A., Yavari, V., Alizade, M., \& Farzanfar, A. (2008). Growth, Survival And Gut Microbial Load Of Rainbow Trout (Onchorhynchus mykiss)
Fry Given Diet Supplemented With Probiotic During The Two Months Of First Feeding. Turkish Journal of Fisheries and Aquatic Sciences, 1, 43-48.

Catalán, N., Villasante, A., Wacyk, J., Ramírez, C., \& Romero, J. (2018). Fermented Soybean Meal Increases Lactic Acid Bacteria in Gut Microbiota of Atlantic Salmon (Salmo salar). Probiotics and Antimicrobial Proteins, 10(3), 566-576. https://doi.org/10.1007/s12602-017-93667

Dachi, A. L., Muhammadar, A. A., Sahidhir, I., Putra, D. F., \& Irwan, Z. A. (2019). Effects Of Probiotics (Rabal) With Different Doses On The Survival, Feed Conversion, And Growth Of Giant Prawns (Macrobrachium rosenbergii). IOP Conference Series: Earth and Environmental Science, 348(1). https://doi.org/10.1088/17551315/348/1/012083

Dawood, M. A. O., Magouz, F. I., Salem, M. F. I., \& Abdel-Daim, H. A. (2019). Modulation Of Digestive Enzyme Activity, Blood Health, Oxidative Responses And Growth-Related Gene Expression In GIFT By Heat-Killed Lactobacillus plantarum (L-137). Aquaculture, 505(February), 127 136.https://doi.org/10.1016/j.aquaculture. 2019.02.053

El-rhman, A. M. A., Khattab, Y. A. E., \& Shalaby, A. M. E. (2009). Micrococcus Luteus And Pseudomonas Species As Probiotics For Promoting The Growth Performance And Health Of Nile Tilapia, Oreochromis niloticus. Fish and Shellfish Immunology, $27 \quad$ (2),175-180. https://doi.org/10.1016/j.fsi.2009.03.020

Fu, C., Li, D., Hu, W., Wang, Y., \& Zhu, Z. (2007). Fast-Growing Transgenic Common Carp Mounting Compensatory Growth. Journal of Fish Biology, 71(SUPPL. B), 174-185. https://doi.org/10.1111/j.10958649.2007.01401.x 
Huisman EA. (1987). Principles of Fish Production. Wageningen, The Netherlands: Departement of Fish Culture and Fisheries, Wageningen Agricultural University.

Hoseinifar, S. H., Sun, Y. Z., Wang, A., \& Zhou, Z. (2018). Probiotics As Means Of Diseases Control In Aquaculture, A Review Of Current Knowledge And Future Perspectives. Frontiers in Microbiology, 9 (OCT), $1-18$. https://doi.org/10.3389/fmicb.2018.02429

Iskandar, R., \& Elrifadah. (2015). Pertumbuhan dan Efisiensi Pakan Ikan Nila (Oreochromis niloticus) yang Diberi Pakan Buatan Berbasis Kiambang. Jurnal Ziraa"ah, 40(1), 18-24.

Jullianty, I., Yulianto, T., \& Miranti, S. (2020). Pengaruh Penambahan Ragi Saccharomyces cerevisiae pada Pakan terhadap Pertumbuhan Benih Ikan Bawal Bintang Trachinotus Blochii. Intek Akuakultur, 4(1), 44-57.

Kordi MGHK. (2009). Budidaya Perairan Jilid II. PT. Citra Aditya Bakti, Bandung.

Leroy, F., \& De Vuyst, L. (2004). Lactic Acid Bacteria As Functional Starter Cultures For The Food Fermentation Industry. Trends in Food Science and Technology, 15(2), 67-78. https://doi.org/10.1016/j.tifs.2003.09.004

Lestari, S. F., Yuniarti, S., \& Abidin, Z. (2014). Pengaruh Formulasi Pakan Berbahan Baku. Jurnal Kelautan,6(1), 36-46.

Mapenzi, L. L., Mtolera, M. S., Koning, D. J., \& Mmochi, A. J. (2021). Efficacy of Lactobacillus Plantarum and Saccharomyces Cerevisiae on Growth Improvement of Hybrid Nile and Rufiji Tilapia Populations, WIO Journal of Marine science. 20 (1), 35-45. https://doi.org/10.1038/278097a0

Nayak, S. (2010). Probiotics and immunity: A fish perspective. Fish and Shellfish
Immunology, 29(1), 2-14.

Noordin, H ., Apriani, I., (2021). Pengaruh Jenis Bakteri Probiotik Terhadap Pertumbuhan Ikan Lele Mutiara Yang Dipelihara Menggunakan Sistem Bioflok. Jurnal Akuakultur Rawa Indonesia, 9(1), 41-48.

Risdianto, D., Jauhul, A., \& Lillah, A. Z. (2016). Aplikasi Probiotik Herbafarm Ikan, Udang Dan Tambak Pada Pemeliharaan Udang Vaname (Litopenaeus Vannamei) Dan Ikan Kerapu Macan Untuk Meningkatkan Produksi Perikanan Nusantara. Prosiding SNST Ke-6 Tahun 2015 Fakultas Teknik Universitas Wahid Hasyim Semarang 51, 51-57.

Setiyaningsih, L., Widanarni, W., Lusiastuti, A. M., \& Yuhana, M. (2018). Pengaruh Pemberian Mikrokapsul Probiotik Bacillus cereus P22 dan Staphylococcus lentus L1k Pada Pakan Terhadap Kinerja Pertumbuhan, Respons Imun, Dan Resistensi Ikan Lele, Clarias gariepinus Burchell 1822 yang diinfeksi Aeromonas hydrophila. Jurnal Iktiologi Indonesia, 17(2), 143. https://doi.org/10.32491/jii.v17i2.354

Syamsunarno MB. \& Sunarno MTD. (2014). Kajian biji karet (Hevea Brasiliensis) sebagai kandidat bahan baku pakan ikan. Jurnal Ilmu Pertanian dan Perikanan, 3(2), 135-142

Surianti, Muaddama, F., Wahyudi, \& Firman, S. W. (2021). Pengaruh Konsentrasi Dedak Padi Terfermentasi Menggunakan Lactobacillus sp. Dalam Pakan Buatan Terhadap Kinerja Pertumbuhan Dan Aktivitas Enzim Ikan Nila, Oreochromis niloticus ( Linnaeus , 1758 ) Jurnal Ikhtiologi Indonesia, 21(1), 11-22.

Sutrisna, R., Ekowati, C., \& Agustin, V. S. (2017). Uji Viabilitas Bakteri Asam Laktat Dari Usus Itik Pada Media Pakan Dedak Padi Dan Kombinasi Dedak Padi Dengan Molases. Jurnal Biologi Eksperimen Dan Keanekaragaman Hayati, 4(2), 7-14. 
Watanabe, T. (1988). Fish Nutrition and Mariculture. Kanagawa Fisheries Training Center, Japan International Cooperation Agency, Tokyo, 233 pp

Weinbreck, F., Bodnár, I., \& Marco, M. L. (2010). Can Encapsulation Lengthen The Shelf-Life Of Probiotic Bacteria In Dry Products? International Journal of Food Microbiology, $136 \quad$ (3), 364-367. https://doi.org/10.1016/j.ijfoodmicro.2009. 11.004 